\title{
THE IMPACT OF CORONAVIRUS ON FINANCIAL MARKETS OF DEVELOPED COUNTRIES
}

\author{
Mehjbeen \\ Student, Master in Economics (Major: Finance), School of Economics, Shandong University, \\ Shandong Province, city: Jinan, China
}

Article DOI: https://doi.org/10.36713/epra7683 DOI No: 10.36713/epra7683

\author{
LIST OF ABBREVATIONS \\ COVID-19 - Coronavirus Disease 2019 \\ SARS - severe acute respiratory syndrome \\ WHO - World Health Organization \\ MFW - Mutual Funds Weekly \\ T.BW - Treasury Bills weekly \\ CDS - Certificate of Deposits weekly \\ BDW - Bonds weekly \\ MTGW - Mortgage weekly \\ S\&P 500 - United States Stock market \\ OSEAX - Norway Stock market \\ DAX - Germany Stock market \\ ISEQ - Ireland Stock Market \\ OM - Sweden Stock Market \\ FSSTI - Singapore Stock Market Index, \\ SMI - Switzerland Stock Market
}

\section{ABSTRACT}

According to the World Health Organization, tens of millions of confirmed cases and hundreds of thousands of confirmed deaths have been registered worldwide. COVID-19, a kind of coronavirus, has emerged as one of the most serious dangers to the global economy and financial markets in human history. The Covid-19 virus's introduction has caused a global reduction in economic activity, perhaps posing new dangers to financial stability. This study aims to look into and reveal the effect of coronavirus on two financial markets. Ten advanced countries' capital market and money market data with the time interval from March 2020 to November 2020 has been used in this study. Six indices of these financial market Shares, Mutual Funds, Treasury Bills, Certificates of Deposits, Bonds, and Mortgages worked as samples. The research has been conducted on advanced nations USA, Norway, Canada, Germany, Ireland, Sweden, Singapore, Netherlands, Australia, and Switzerland. Panel Regression Analysis, Spearman's rank correlation, and ANOVA are used to estimate the study results. The scholar constructs a weekly panel data of COVID- 19 confirmed cases and financial market indices. The second purpose is to calculate the Risk on the six chosen indices of these markets. COVAR methodology is used to measure the risks among capital market and money markets indices. Interestingly, this research noticed that all financial markets impacted by the coronavirus while the capital market has recorded maximum fluctuations and the stock market show minimum volatility. The final results give a detailed understanding of financial market indices. It will support future research on other money and Capital markets indices and investors after the Coronavirus period.

KEYWORDS: Coronavirus, Financial Markets, COVAR, COVID-19 Confirmed Cases. Capital Market. Money Market, Developed economies, 


\section{INTRODUCTION}

At Wuhan Central Hospital in China, a doctor Li Wenliang warned about the coronavirus outbreak. Coronavirus is known as COVID19, appeared as a black swan event that muffled the global economy. According to the WHO, almost 5.7 million new cases were recorded in the last week of April 2021 exceeded the previous peaks (World Health Organization 2021). Over 87000 additional deaths were reported as a result of the rise in the number of new deaths. Although some countries in the region are reporting positive trends, India accounts for the vast majority of cases in this international pattern, accounting for 38\% of global cases recorded in April 2021 figure 1.

This disease outburst is becoming the most critical monetary and joint event in olden human times, with extensive financial consequences (Laing 2020). COVID-19 signifies unique pressures to financial stability and compact economic activity universal (Arnoud, Boot, and Schaefer 2020). Coronavirus affects not only economies but all aspects of life. Like financial markets, for example, Stock markets, Banks, Capital Markets, and Money markets. This research mainly focuses on the influence of COVID19 on financial market indices and measured systematic Risk in these financial markets of ten developed countries. Besides the instantaneous disasters of demise and sickness, unintended effects over distress are enchanting hold worldwide. The anxiety related to the number of expiries stated has raised a sagacity of emergency, and international fright is distributed quicker than the disease's blowout (Aslam, Mohti, and Ferreira 2020).

Financial Markets is the combination of two submarkets in this study comprise of Capital markets and money markets. Stock Markets is one of the main parts of the Capital market. Share exchanges, also known as financial markets or share markets, are made up of buyers and sellers of stocks, representing ownership interests in companies. Securities listed on a communal stock exchange are one example. This study measures the Risk on these markets, and its indices have been suffering due to coronavirus disaster. People expect war, political problems, natural earthquake disasters to destroy the economy. But this virus changes the whole economy and life system very severely. Thus, the research determination is to examine whether Coronavirus increases the volatility of the money market and capital market or not? And which country is affected more due to this Covid19 disaster.

\section{LITERATURE REVIEW}

The COVID19's impact is critical, especially since the virus's first breakout occurred in China, Asia's largest center for foreign investment. Researchers think COVID-19 and SARS are related, yet the two diseases have substantial differences. This research discusses the influence of COVID-19 on capital and money market instruments, and it might be compared to much earlier research on the economic implications of infectious viral epidemics.

\section{IMPACTS OF SARS ON FINANCIAL MARKETS}

Hong Kong was one of the nations cruelly influenced by the episode of SARS; in any case, there was no overwhelming effect initiate within the stock exchange (Siu and Wong 2004). In the background, Taiwan (C.-D. Chen et al. 2009) considered the influences of the SARS flare-up on the stock market amid the historical outburst in 2003. They individually calculated the impacts on specific businesses, counting air companies, travel, marketing stores, and biotechnology divisions. Accumulated Data of 32 firms Using the event study method to examine the data, their outcomes showed that the SARS outbreak negatively obstructed airlines and the tourism and retail store subdivisions.

To find a time-varying co-integration connection between China and the other four Asian markets, (M. P. Chen et al. 2018) using the progressive, smooth time-varying co-integration model. Hong Kong, Taiwan, Singapore, and Japan. Prolonged the study time from 1998 to 2008, which secured the five years earlier and later the SARS epidemic. Their results exposed that the SARS flare-up harmfully influenced the long-term connection between China and the four markets.

\section{IMPACT OF COVID-19 ON FINANCIAL MARKETS}

The heightening of the disaster could mark the global financial firmness Global Financial Stability Report, 2020.As examined in an alternative just-published report called the crisis "The Great Lockdown," the plague seems agreement on the worldwide economy by 3 percent, which is much more awful than the worldwide financial crisis of 2008 to 2009 World Economic Outlook, 2020.

The negative impact of COVID-19 on the financial market has complicated risk control and enforcement (Andries et al. 2020). (W. Huang and Zheng 2020) claimed the effect of COVID19 on crude oil rates and stock values in the US. (Nicola et al. 2020) study the impact of Covid19 on U.S. stock market uncertainty. Markov 
Converting AR model was used to understand management transformation from inferior to advanced volatility. Both positively and negatively, COVID19 information is significant, even though the negative broadcast is much more robust, representing a bad bias. Significant improvements in average and alternative intimidations are reported throughout all markets, whereas swings in capital structure vary crosswise sector.

A heavy demand impact combined with massive supply-side assistance responsibly. (Daube, 2020) reported that the coronavirus COVID19 created enormous chaos in the global capital markets.

(Sciences, Issn, and Apr 2020) used a simple regression model to check the impact of the COVID 19 on China and the USA's financial marketplaces. (Khan et al. 2020) inspect the effect of COVID19 widespread on the stock marketplaces of 16 nations.

(Ramelli and Wagner 2020) studied the market responses to the COVID19 pandemic and discovery that the widespread intensifies the economic disaster. (Boubaker and Sensoy 2020) sightsee the financial infection through financial and non-financial firms between China and G7 countries during the COVID 19 pandemic and invention the COVID19 increases the connections between registered companies.

(D. Wang, Li, and Huang, n.d.) work on the instability spillovers amongst main global financial markets throughout the COVID19 epidemic with Diebold and Yilmaz's connectedness index and

discover that the COVID19 widespread meaningfully impacts the worldwide financial markets countries with unadorned epidemics. (Sharif, Aloui, and Yarovaya 2020) apply the consistency wavelet method and Granger causality test to examine the connectedness between the shock market, geopolitical danger, the recent blow-out of COVID19, economic strategy ambiguity, and oil price unpredictability shock US (P. Li, Guo, and Li 2020) calculate the systemic jeopardy instigated by avoidance infection amongst banks' inner markets founded on random network graphs. (Eckel et al. 2011) explained stock yields in numerous financial markets and stock returns between financial markets are associated with the geographic site.

There is a link between stock market returns and pandemic outbreaks, according to the existing research. (Ozili and Arun 2020b), (Barua 2020), (H. Liu et al. 2020), (Azimli 2020). As a result, several past studies claim that Capital market swings caused by epidemics have resulted in large economic losses in Financial markets. (Shehzad, Xiaoxing, and Kazouz 2020) (Osagie, Maijamaa, and Owoicholofu 2020a), (Panizza, n.d.), (Mohanty, Patnaik, and Satpath 2020), (S. R. Baker et al. 2020), (H. Liu et al. 2020), (Yilmazkuday 2020), (Lee 2017), (Lucey and Voronkova 2008), (Balcerzak et al. 2017), ("EFFECT OF COVID 19 ON CAPITAL MARKET WITH REFERENCE TO S\&P 500 Shreeram Thakur 1 July1, 2020” 2020).

\section{COVAR AND FINANCIAL MARKETS}

(Adrian and Brunnermeier 2011) highlight, in the COVaR quantity, the preface "Co" stands for conditional, contagion, or co-movement. Conditionality of COVaR does not narrate to causality COVaR does not openly transport whether the same organization's universal status as a basis of contamination is due to a fundamental association.

The consequence of experience to mutual issues, so this feature makes COVaR and COVaR the accurate actions when using the comprehensive desscription of the deliberate spectacle. Further structures of the COVaR technique that allowed us to attain the established goal line be situated

(Adrian and Brunnermeier 2008). The conditional value at Risk (COVaR) not only captures the systemic Risk rooted in the financial classification but likewise reflects different institute's involvement in it, taking tail risk addiction. In the previous few years, Conditional Value at risk COVaR has been approved in numerous fields like finance risk supervision, insurance, and energy, a rapid incline of references contains (Kuester, Mittnik, and Paolella 2006).

In instantaneous, current studies only examined the impact of COVID19 on the most important indices of a specific country even though roughly studies focused on investigating some exaggerated subdivisions. This effort purposes of subsidizing the delivery of information of the capital market and stock market indices. And no one work has done on money market before. Therefore, this study aims to replenish the information opening by examining the affiliation between the COVID19 outbreak and the responses of different financial market indices and measured the Risk on all financial markets due to COVID-19 COVAR methodology, compared before and during coronavirus period performance of all financial markets.

\section{The Empirical Objectives}

The aim of this research is divided into the following objectives;

- To assess the impact of Coronavirus's (positive or negative) on Capital Markets and Money markets on developed nations and which developed countries are mostly affected due to the coronavirus crisis. 
- To measure the systematic risk in all financial market indices through COVAR methodology.

\section{METHODOLOGY}

Data: In this paper panel weekly data collected from the secondary data collection technique, i.e., WHO corona dashboard, USA treasury online directory, online statistics of Norges Bank, Norway, online resources of the bank of Canada, Statista a globally renowned online directory for insights, YCharts trading economy from March 2020 to November 2020. To verify the relationship between independent and dependent variable different statistical analysis has been performed, i.e., descriptive analysis, Spearman's rank correlation, ANOVA and mainly panel data regression (i.e., linear regression) the strength of study on SPSS v. 23.0. the empirical investigation is associated with the COVID19 confirmed cases, to demonstrate the influence of the coronavirus on financial market indices, which are stock indices like (shares, Mutual funds), Capital market indices (Bonds, Mortgages ${ }^{1}$ ) likewise Money markets indices (Treasury bills, certificate of deposits) are included from each country taking as the sample. As a result, six different capital markets and money market indices reflect the situation's corresponding financial markets selecting the most settled countries in the world. The sample selection is constructed on the availability of data for all variables.

\section{Description of Variables and Model Specification:}

There is one independent variable used in this study coronavirus confirmed cases. And for dependent variable Capital and money markets indices shares, Mutual Fund, Mortgage, Bond Yield, Treasury Bill, Certificate of Deposit are included. The effect of coronavirus cases on these indices will be accessed in this research.

\section{Method of data analysis:}

$$
Y_{i t}=\beta_{o}+\beta_{1} X_{i t}+\mu_{i t}
$$

$\left(Y_{i t}\right)$ represents the dependent variable which is the indices of financial markets. $\left(\boldsymbol{X}_{i t}\right)$ is defining the independent variable, which is COVID-19 Cases in this study.

$S H R W=\beta_{o}+\beta_{1}$ COVID_19 Cases $+\boldsymbol{\mu}_{\text {it }}$ reveals that the quantity of coronavirus19 cases, the sum of weeks, the region, and the country's valuation all directly impact the parameter of stock market index shares. MFW $=\boldsymbol{\beta}_{o}+\boldsymbol{\beta}_{1}$ COVID_19 Cases $+\boldsymbol{\mu}_{\text {it }}$ is interpreting the second index Mutual Funds.

$B D W=\beta_{o}+\beta_{1} C$ OVID_19 Cases $+\mu_{\text {it }}$ shows how much percentage change occurs in the value of bonds due to coronavirus19 confirmed cases change. $M T G W=\beta_{o}+\beta_{1}$ COVID_19 Cases $+\mu_{i t}$ weekly Mortgages units will change within the weekly coronavirus-19 case and change in selected countries. T. $B W=\beta_{o}+\beta_{1}$ COVID_19 Cases $+\mu_{i t}$ Treasury Bills, tells us how many units will change when the change happens to the number of coronavirus cases. $C D W=\beta_{o}+\beta_{1}$ COVID_19 Cases $+\mu_{\text {it }}$ explains the effect of coronavirus 19 cases on the index of certificates of deposits that measure the money market index.

\section{DESCRIPTIVE ANALYSIS OF TREASURY BILLS AND CERTIFICATE OF DEPOSITS:}

Table 2 shows that Switzerland's correlation of Treasury bill with covid-19 has mostly been affected with the lowest coupon equivalent rate (CER) of -0.93 . For Switzerland, Covid-19 become a nightmare as its recorded maximum coupon equivalent rate (CER) was -0.62 in the outbreak. Switzerland's Treasury bill has the lowest CER over the period; it is also pertinent to mention here the CER of Switzerland has already low compared to other countries.

Certificate of deposit CDS value of Netherland hit a lot by Covid-19 as its value record the lowest over nine months with 8.40 CDS value, father Netherlands, Sweden, Germany as well as Switzerland also impacted with an increasing case of Covid-19 as 10.00, 10.80 and 10.20 respectively. in the given period of 9 months, the USA, Ireland, and Canada with maximum CDS 184.00, 43.20, and 34.50 respectively show less dropdown situation, as shown in Table 01. It is also worth notice that the USA CDS values abruptly touch the ground in the last week of July. It is also

\footnotetext{
${ }^{1}$ Sweden and Singapore mortgage values are missing because research conducted at very early stage.
} 
noticed that Ireland's CDS values are the one who shows certainly deviant behavior, as it raises from the last week of March to the middle of May.

\section{DESCRIPTIVE ANALYSIS OF INVESTMENT OVER BONS AND MORTGAGES}

Investment over the bond, i.e., bond yield, is considered an important instrument for the capital markets worldwide; Switzerland with 82.00 and Netherland with -54.01 bond yield remains the minimum value with the Std. Deviation of 9.24001 and 7.73854 indicates the most affected bond yield throughout the period. It is also pertinent to mention that Switzerland is already suffering because its maximum value was not more than -39.00 bond yield, as shown in table 3. However, Australian bond yield is the only instrument out of all big economies which could maintain the stable value of bond yield and maximum stability in the given period.

The mortgage interest rate of Norway remains the least value of interest rate, then all, down to -0.0060 with std. Deviation of 0.004255 . Whereas the USA mortgage interest rate sustains the highest value, i.e., 2.2100, in the given period, as shown in table. The mortgage interest rates showed very deflecting results from others; most countries have stable interest rates during the 36 weeks, especially the Netherlands, Australia, and Switzerland as Canada has a more stable interest rate.

\section{DESCRIPTIVE ANALYSIS OF SHARE AND MUTUAL FUND}

Among all 360 observations from each country, $n=36$ observations have been collected from March to November 2020. The trading volume of shares is considered an important instrument for the stock markets worldwide; Germany shows a minimum value of 0.14 . The Netherland has a 0.25 trading volume share with the Std. Deviation of .20015 and .14387 indicates that the trading volume has mostly affected the period, as shown in table 3. Most countries have declined in their trading volume of the country's claim during the 36 weeks, especially Netherlands, Australia, Switzerland, and Sweden, as Canada has the more stable trading volume of a share over time. The exchange of mutual funds is considered an important instrument for the stock markets; Netherland worldwide shows a minimum value of 11.40 and Switzerland with 0.20 the exchange of mutual funds with the Std. Deviation of 3.03336 and .27927 indicates that the exchange of mutual funds has mostly affected throughout the time period, as shown in Table. Switzerland, Germany, and specifically Singapore faces many downfalls on the exchange of mutual funds and much fluctuate during the time.

It is clear that money market instrument has also shown great depression as a rise in the covid-19 cases, similar to the relationship between independent and dependent variables, the $\mathrm{R}^{2}$ Change and $\mathrm{R}$ values, 0.926 and 0 . 962a respectively narrates the substantial impact of the certificate of deposit on the special population of the study. The interest rates are comparatively unstable; despite minor fluctuation, the mortgage is the vital capital market instrument. Its value remains stable after instability, which negates the hypothesis and verifies that Covid-19 does not impact the capital market. However, few countries' interest rates show great depression and much fluctuation, which offers a mixed tendency shown in table 5.

This is clear from the regression model, i.e., $\mathrm{R}^{2}=0.920$, that the trading volume of share has much insignificant impact due to the Covid-19 because as the case increase, the trading volume of share comparatively much unstable, despite minor fluctuation the trading volume of the share as the important instrument of the stock market. $R^{2}=0.923$, that the exchange of mutual funds has much insignificant impact due to the Covid-19, because as the case increase, the discussion of mutual funds comparatively much unstable, despite minor fluctuation in the exchange of mutual funds as the essential instrument of the Stock market. Few countries mutual fund exchange show great depression and much instability, which offers a mixed tendency as given in table.

\section{COVAR ANALYSIS}

$$
\text { VaR }=[\mathbf{E W R}-(\mathbf{Z} * \mathbf{S T D})] * \mathbf{P V}
$$

Where Var is the value at risk, EWR is the expected weighted return of the portfolio, and Z is the $\mathrm{z}$ score, and STD is the standard deviation, PV is the portfolio value. In Money Market, the VAR (95) for the expected fluctuation narrate that Norway, Germany, and Switzerland are most expected to highly impact due to Covid-19 while Canada, USA, and Ireland relevantly less expectation of drawn in lose have shown by COVAR Analysis. In the Capital Market, similar to the money market, the VAR (95) values for the capital markets show some immediate risk for the USA, Sweden, and Australia, but the rest of the markets relevantly less risk to fluctuate. The stock market has comparatively shown different behavior than the other markets, e.g., USA Norway Germany and the Netherlands have the Var (95) values > 40 In contrast, Canada and Singapore have no immediate risk of loss or serious 
fluctuation in the stock market. Hence it could conclude that the probability of instability is high in the select period of time. Analytical details have been given below in Table 6 .

\section{CONCLUSION}

Like a black swan occurrence that suppressed the financial system, COVID-19 appeared. The consequence of COVID-19 was economic fragmentation within nations, controlled immigration, company losses, job losses, market closings, and many other deteriorating socio-economic impacts. In the wake of the crisis, volatility in the stock markets soared, most likely due to the uncertainty of calculating the magnitude of the economic harm caused by this continuing global occurrence. It is concluded that covid-19 have an evident influence on the financial markets, and almost all economies have faced this fluctuation of the graph, e.g., capital, and money market have encountered more or less downfall in a pandemic.

Numerous damaging effects of COVID19 on the stock and money market while the capital market has recorded maximum fluctuations, but the stock market has shown minimum fluctuations. In our study, Switzerland was the country that has affected mainly by COVID-19. Some countries are going into the great depression, but almost all face a downfall in the nine months. Still, the tendency and regression model predict that it will take time to recover the previous position because collectively, all considered countries $(n=10)$ face the great depression after the economic crisis of 2008. As outbreaks of new diseases are improbable to disappear in the immediate future, concentrated international action is needed to save lives and uphold economic prosperity.

\section{LISTS OF TABLES}

Table 1: Description of variables

\begin{tabular}{|c|c|c|}
\hline Financial Markets & Variables & Measurement \\
\hline \multirow[t]{4}{*}{$\begin{array}{l}\text { Capital } \\
\text { Market \& Stock } \\
\text { Market }\end{array}$} & Bond Yield & Bond Yield= Annual Coupon Payment/ Bond Price \\
\hline & Mortgage & Mortgage $=($ Interest rate/number of payment $) *$ Principal loan \\
\hline & Stock Share & $\begin{array}{c}\text { IndexLevel }=\frac{\sum_{i=1}^{n} P_{i} \times Q_{i}}{\text { Divisor }} \\
\text { Pi=Price } \\
\text { Qi=Free-float shares }\end{array}$ \\
\hline & Mutual Fund & $\begin{array}{c}\text { Total return }=\left(\begin{array}{c}\text { Ending investment price }- \text { initial investment } \\
\text { price })\end{array}\right. \\
\text { / Initial investment price }\end{array}$ \\
\hline \multirow[t]{2}{*}{ Money Market } & Treasury Bill & $\begin{array}{c}\mathrm{CER}=\{(\text { Face Value }- \text { Market Price }) / \text { Market Price }\} \\
*\{360 / \text { Days Until Maturity }\}\end{array}$ \\
\hline & $\begin{array}{l}\text { Certificate of } \\
\text { Deposit }\end{array}$ & $\begin{array}{c}\mathrm{CDS}=\mathrm{P}^{*}(1+\mathrm{r})^{\wedge} \mathrm{n} ; \mathrm{r}=(1+\mathrm{APY})^{\wedge}(1 / \mathrm{n}) \\
\mathrm{V}=\text { current value } \\
\mathrm{P}=\text { principal } \\
\mathrm{APY}=\text { annual percentage yield (interest rate bank quotes you }) \\
\mathrm{r}=\text { period interest rate }(\text { calculated using second formula }) \\
\mathrm{n}=\text { periods }\end{array}$ \\
\hline
\end{tabular}


Table2: Descriptive Statistical Analysis of Treasury Bills and Certificate of Deposits in Covid-19

\begin{tabular}{|c|c|c|c|c|c|c|c|c|c|}
\hline \multirow{2}{*}{ COVID-19 } & \multirow{2}{*}{$\mathbf{N}$} & \multicolumn{2}{|c|}{ MIN } & \multicolumn{2}{|c|}{ MAX } & \multicolumn{2}{|c|}{ MEAN } & \multicolumn{2}{|c|}{ SD } \\
\hline & & T. B & C.D & T. B & C.D & T. B & C.D & T. B & C.D \\
\hline Cases & 36 & \multicolumn{2}{|c|}{66} & \multicolumn{2}{|c|}{11597979} & \multicolumn{2}{|c|}{4039014} & \multicolumn{2}{|c|}{3388299} \\
\hline USA & 36 & .00 & 184.00 & 10.00 & 184.00 & .4311 & 22.4139 & 1.66035 & 27.73926 \\
\hline Norway & 36 & -.10 & 16.30 & 1.33 & 16.30 & .1225 & 12.9944 & .31386 & 1.80538 \\
\hline Canada & 36 & .12 & 34.50 & 31.00 & 34.50 & 1.1883 & 33.2278 & 5.19682 & .44697 \\
\hline Germany & 36 & -.76 & 23.60 & .50 & 23.60 & -.5874 & 14.8222 & .20015 & 4.55344 \\
\hline Ireland & 36 & .22 & 43.20 & .96 & 43.20 & .5786 & 27.0528 & .29580 & 6.35239 \\
\hline Sweden & 36 & -.52 & 15.70 & .07 & 15.70 & -.0869 & 12.4250 & .10485 & 1.63731 \\
\hline Singapore & 36 & .22 & 24.30 & .27 & 24.30 & .2422 & 19.1806 & .01222 & 3.28310 \\
\hline Netherland & 36 & -.65 & 18.80 & -.11 & 18.80 & -.4203 & 13.0389 & .14387 & 3.03336 \\
\hline Australia & 36 & .40 & 38.80 & .87 & 38.80 & .7094 & 22.6250 & .10387 & 7.35917 \\
\hline Switzerland & 36 & -.93 & 15.70 & -.62 & 15.70 & -.7886 & 12.5639 & .06921 & 1.50810 \\
\hline
\end{tabular}

Table 3: Descriptive Analysis of Investment over bonds and Mortgages of Countries in Covid-19

\begin{tabular}{|c|c|c|c|c|c|c|c|c|c|}
\hline \multirow{2}{*}{ COVID-19 } & \multirow{2}{*}{$\mathbf{N}$} & \multicolumn{2}{|c|}{ MIN } & \multicolumn{2}{c|}{ MAX } & \multicolumn{2}{c|}{ MEAN } & \multicolumn{2}{c|}{ SD } \\
\cline { 3 - 10 } & & BD & MTG & BD & MTG & BD & MTG & BD & MTG \\
\hline Cases & 36 & \multicolumn{2}{|c|}{66} & \multicolumn{2}{|c|}{11597979} & \multicolumn{2}{|c}{4039014} & \multicolumn{2}{c|}{3388299} \\
\hline USA & 36 & .62 & .0079 & .87 & 2.2100 & .7231 & .090764 & .08006 & .3633332 \\
\hline Norway & 36 & 51.00 & -.0060 & 110.00 & .0094 & 68.5278 & .002978 & 16.58138 & .0042558 \\
\hline Canada & 36 & 73.00 & .0082 & 129.00 & 1.4600 & 97.2778 & .054294 & 11.93940 & .2409838 \\
\hline Germany & 36 & -49.00 & .0119 & -.42 & .0186 & -1.8503 & .012697 & 8.08299 & .0010622 \\
\hline Ireland & 36 & -32.00 & .0282 & 20.00 & .0288 & -2.8889 & .028486 & 15.06325 & .0001959 \\
\hline Sweden & 36 & -33.00 & .0442 & 21.00 & 1.4960 & -8.3889 & .090294 & 10.82663 & .2409838 \\
\hline Singapore & 36 & 10.05 & .0349 & 843.60 & 2.2310 & 108.4274 & .111931 & 128.54576 & .3632954 \\
\hline Netherland & 36 & -54.01 & .0263 & -28.20 & .0337 & -41.0714 & .029981 & 7.73854 & .0022309 \\
\hline Australia & 36 & 79.62 & .0220 & 89.68 & .0283 & 84.6456 & .025172 & 3.02867 & .0018390 \\
\hline Switzerland & 36 & -82.00 & .0010 & -39.00 & .0032 & -51.2222 & 0.0021 & 9.24001 & 0.0011 \\
\hline
\end{tabular}

Table 4: Descriptive Analysis of Trading Volume of the share and the Mutual Funds of Countries in Covid-19

\begin{tabular}{|c|c|c|c|c|c|c|c|c|c|}
\hline \multirow{3}{*}{$\begin{array}{c}\text { COVID-19 } \\
\text { Cases }\end{array}$} & \multirow{2}{*}{$\mathbf{N}$} & \multicolumn{2}{|c|}{ MIN } & \multicolumn{2}{|c|}{ MAX } & \multicolumn{2}{|c|}{ MEAN } & \multicolumn{2}{|c|}{ S. D } \\
\hline & & MF & SHR & MF & SHR & MF & SHR & MF & SHR \\
\hline & 36 & \multicolumn{2}{|c|}{66} & \multicolumn{2}{|c|}{11597979} & \multicolumn{2}{|c|}{4039014} & \multicolumn{2}{|c|}{3388299} \\
\hline USA & 36 & 18.20 & .90 & 23.10 & 2.30 & 20.8139 & 1.0561 & 1.46972 & .25689 \\
\hline Norway & 36 & 13.20 & .80 & 19.30 & 2.23 & 15.9944 & 1.0225 & 1.80538 & .31386 \\
\hline Canada & 36 & 35.20 & 1.02 & 37.50 & 31.90 & 36.2278 & 2.0622 & .44697 & 5.12443 \\
\hline Germany & 36 & 13.80 & .14 & 26.60 & 1.40 & 17.8222 & .3126 & 4.55344 & .20015 \\
\hline Ireland & 36 & 22.60 & 1.12 & 46.20 & 1.86 & 30.0528 & 1.4786 & 6.35239 & .29580 \\
\hline Sweden & 36 & 13.00 & .38 & 18.70 & .97 & 15.4250 & .8131 & 1.63731 & .10485 \\
\hline Singapore & 36 & 17.30 & 1.12 & 27.30 & 1.17 & 22.1806 & 1.1422 & 3.28310 & .01222 \\
\hline Netherland & 36 & 11.40 & .25 & 21.80 & .79 & 16.0389 & .4797 & 3.03336 & .14387 \\
\hline Australia & 36 & 17.30 & 1.30 & 41.80 & 1.77 & 25.6250 & 1.6094 & 7.35917 & .10387 \\
\hline Switzerland & 36 & 2.20 & 2.20 & 3.80 & 3.80 & 2.5457 & 2.5457 & .27927 & .27927 \\
\hline
\end{tabular}


Table 5: Regression Model Summary

\begin{tabular}{|c|c|c|c|c|c|c|c|c|c|}
\hline \multirow[b]{2}{*}{ Model } & \multirow[b]{2}{*}{$\mathbf{R}$} & \multirow[b]{2}{*}{$R^{2}$} & \multirow{2}{*}{$\underset{R^{2}}{\text { Adjusted }}$} & \multirow{2}{*}{$\begin{array}{l}\text { Std. The error of } \\
\text { the Estimate }\end{array}$} & \multicolumn{5}{|c|}{ Change Statistics } \\
\hline & & & & & $\begin{array}{c}\boldsymbol{R}^{2} \\
\text { Change }\end{array}$ & $\begin{array}{c}\text { F } \\
\text { Change }\end{array}$ & df1 & df2 & $\begin{array}{c}\text { Sig. F } \\
\text { Change }\end{array}$ \\
\hline T. B & .962 & .925 & .893 & 1114639.7623 & .925 & 29.479 & 10 & 24 & .000 \\
\hline CDS & $.962^{\mathrm{a}}$ & .926 & .896 & 1090476.66816 & .926 & 31.291 & 10 & 25 & .000 \\
\hline MTG & $.989^{\mathrm{a}}$ & .979 & .973 & 553660.7956523 & .979 & 183.260 & 7 & 28 & .000 \\
\hline SHR & $.959^{\mathrm{a}}$ & .920 & .888 & 1135664.46140 & .920 & 28.655 & 10 & 25 & .000 \\
\hline MF & $.961^{\mathrm{a}}$ & .923 & .892 & 1115603.63325 & .923 & 29.786 & 10 & 25 & .000 \\
\hline & & & & ndent Variable & en & & & & \\
\hline
\end{tabular}

Table 6: COVAR Analysis of Different Countries' Money, Capital, and Stock Market

\begin{tabular}{|c|c|c|c|}
\hline \multirow{2}{*}{ Countries } & \multicolumn{3}{|c|}{ VAR (95) = Expected Loss\% } \\
\cline { 2 - 4 } & Money Market & Capital Market & Stock Market \\
\hline USA & $24.1 \%$ & $52.5 \%$ & $49.3 \%$ \\
Norway & $48.3 \%$ & $-24.4 \%$ & $48.3 \%$ \\
Canada & $-39.5 \%$ & $-16.0 \%$ & $-38.2 \%$ \\
Germany & $50.3 \%$ & $-41.4 \%$ & $50.3 \%$ \\
Ireland & $48.6 \%$ & $-21.1 \%$ & $48.6 \%$ \\
Sweden & $52.1 \%$ & $10.8 \%$ & $52.1 \%$ \\
Singapore & $53.7 \%$ & $-14.8 \%$ & $-53.7 \%$ \\
Netherland & $51.4 \%$ & $-22.0 \%$ & $51.4 \%$ \\
Australia & $52.1 \%$ & $7.7 \%$ & $43.8 \%$ \\
Switzerland & $68.1 \%$ & $3.0 \%$ & $52.1 \%$ \\
\hline
\end{tabular}

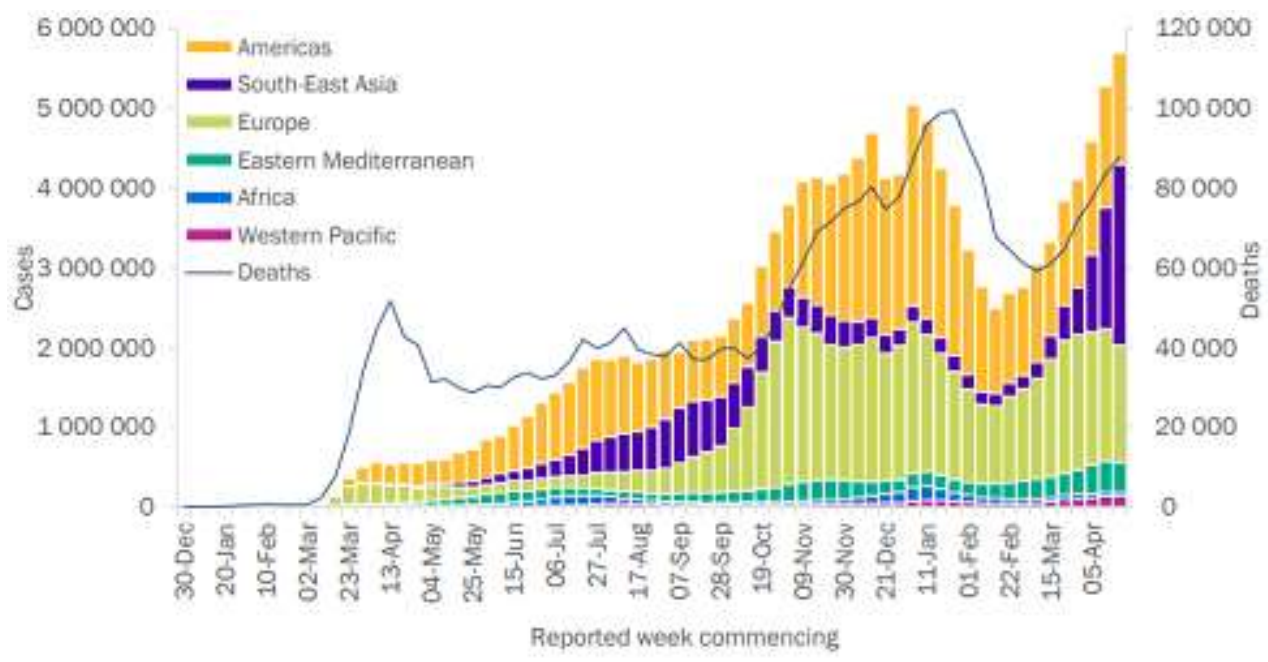

COVID-19 Cases Weekly Reported Cases and global deaths Figure 1: Source. World Health Organization (WHO) 


\section{REFERENCES}

1) World Health Organization, “COVID-19 Weekly Epidemiological Update 22,” World Heal. Organ., no. December, pp. 1-3, 2021, [Online]. Available: https://www.who.int/docs/default.

2) T. Laing, "The economic impact of the Coronavirus 2019 (Covid-2019): Implications for the mining industry," Extr. Ind. Soc., vol. 7, no. 2, pp. 580-582, 2020, doi: 10.1016/j.exis.2020.04.003.

3) W. A. Arnoud, A. Boot, and S. Schaefer, "www.econstor.eu," 2020.

4) F. Aslam, W. Mohti, and P. Ferreira, "Evidence of intraday multifractality in european stock markets during the recent coronavirus (Covid-19) outbreak,” Int. J. Financ. Stud., vol. 8, no. 2, pp. 1-13, 2020, doi: 10.3390/ijfs8020031.

5) Siu and Y. C. R. Wong, "Economic Impact of SARS: The Case of Hong Kong," Asian Econ. Pap., vol. 3, no. 1, pp. 6283, 2004, doi: 10.1162/1535351041747996

6) C.-D. Chen, C.-C. Chen, W.-W. Tang, and B.-Y. H. Huang, "The Positive and Negative Impacts of the Sars Outbreak: A Case of the Taiwan Industries Author (s): Published by: College of Business, Tennessee State University Stable URL: https://www.jstor.org/stable/40376284 THE POSITIVE AND NEGATIVE IMPACTS OF T, ” J. Dev. Areas, vol. 43, no. 1, pp. 281-293, 2009.

7) M. P. Chen, C. C. Lee, Y. H. Lin, and W. Y. Chen, "Did the S.A.R.S. epidemic weaken the integration of Asian stock markets? Evidence from smooth time-varying cointegration analysis, ” Econ. Res. Istraz. , vol. 31, no. 1, pp. 908-926, 2018, doi: 10.1080/1331677X.2018.1456354.

8) M. Andries, S. R. G. Ongena, N. Sprincean, and R. Tunaru, "Risk Spillovers and Interconnectedness between Systemically Important Institutions,”SSRN Electron. J., 2020, doi: 10.2139/ssrn.3597962.

9) W. Huang and Y. Zheng, "COVID-19: Structural Changes in the Relationship Between Investor Sentiment and Crude Oil Futures Price,” Energy Res. Lett., vol. 1, pp. 1-5, 2020, doi: 10.46557/001c.13685.

10) M. Nicola et al., "The socio-economic implications of the coronavirus pandemic (COVID_19): A review," Int. J. Surg., vol. 78, no. March, pp. 185-193, 2020, doi: 10.1016/j.ijsu.2020.04.018.

11) K. Khan, H. Zhao, H. Zhang, H. Yang, M. H. Shah, and A. Jahanger, "The impact of COVID-19 pandemic on stock markets: An empirical analysis of world major stock indices, "J. Asian Financ. Econ. Bus., vol. 7, no. 7, pp. 463-474, 2020, doi: 10.13106/jafeb.2020.vol7.no7.463.

12) S. Ramelli and A. F. Wagner, "Feverish Stock Price Reactions to," vol. 9, pp. 622-655, 2020, doi: $10.1093 / r c f s / c f a a 012$.

13) S. Boubaker and A. Sensoy, "Financial contagion during COVID-19 crisis," Financ. Res Lett., p. 101604, 2020, doi: 10.1016/j.frl.2020.101604.

14) D. Wang, P. Li, and L. Huang, "Volatility Spillovers between Major International Financial Markets During the COVID-19 Pandemic."

15) Sharif, C. Aloui, and L. Yarovaya, "International Review of Financial Analysis COVID-19 pandemic, oil prices, stock market, geopolitical risk and policy uncertainty nexus in the US economy: Fresh evidence from the wavelet-based approach," Int. Rev. Financ. Anal., vol. 70, no. May, p. 101496, 2020, doi: 10.1016/j.irfa.2020.101496

16) P. Li, Y. Guo, and A. Li, “Jo ur l P re of," Int. Rev. Financ. Anal., p. 101649, 2020, doi: 10.1016/j.irfa.2020.101649.

17) S. Eckel, G. Löf, A. Maurer, and V. Schmidt, "Measuring the effects of geographical distance on stock market correlation," vol. 18, pp. 237-247, 2011, doi: 10.1016/j.jempfin.2010.12.001.

18) K. Shehzad, L. Xiaoxing, and H. Kazouz, "COVID-19's disasters are perilous than Global Financial Crisis: A rumor or fact?” Financ. Res. Lett., vol. 36, p. 101669, 2020, doi: 10.1016/j.frl.2020.101669.

19) M. Osagie, B. Maijamaa, and D. Owoicholofu, "On the Effects of COVID-19 outbreak on the Nigerian Stock Exchange performance: Evidence from GARCH Models," no. April, 2020, doi: 10.20944/preprints202004. 0444.v1.

20) K. Kuester, S. Mittnik, and M. S. Paolella, "Value-at-Risk Prediction: A Comparison of Alternative Strategies," vol. 4, no. 1, pp. 53-89, 2006, doi: 10.1093/jjfinec/nbj002.

21) T. Adrian and M. K. Brunnermeier, “COVAR. Working Paper 17454,” Natl. Bur. Econ. Res., 2011.

22) T. Adrian and M. K. Brunnermeier, "Federal Reserve Bank of New York Staff Reports CoVaR," no. September, 2008.

23) "EFFECT OF COVID 19 ON CAPITAL MARKET WITH REFERENCE TO S\&P 500 Shreeram Thakur 1 Julyl, 2020,”2020.

24) P. Balcerzak, C. Republic, M. Zinecker, and C. Republic, "SHORT-TERM SHOCKS AND LONG- TERM RELATIONSHIPS OF INTERDEPENDENCIES AMONG CENTRAL EUROPEAN CAPITAL,” vol. 10, no. 1, pp. 6177, 2017, doi: 10.14254/2071-789X.2017/10-1/5.

25) M. Lucey and S. Voronkova, "Journal of International Money Russian equity market linkages before and after the 1998 crisis: Evidence from stochastic and regime-switching cointegration tests,” J. Int. Money Financ., vol. 27, no. 8, pp. 1303-1324, 2008, doi: 10.1016/j.jimonfin.2008.07.004.

26) H. Liu, A. Manzoor, C. Wang, L. Zhang, and Z. Manzoor, "The COVID-19 Outbreak and Affected Countries Stock Markets Response," no. Table 1, pp. 1-19, 2020. 